\title{
SCREENING AND IDENTIFICATION OF HEAVY METAL-TOLERANT ENDOPHYTIC FUNGI LASIODIPLODIA THEOBROMAE FROM BOSWELLIA OVALIFOLIOLATA AN ENDEMIC PLANT OF TIRUMALA HILLS
}

\author{
SANI AISHWARYA ${ }^{1}$, VENKATESWARULUNAGAM ${ }^{2}$, VASUDEVA REDDY NETALA ${ }^{1}$, VIJAYA TARTTE ${ }^{2}$ \\ ${ }^{1}$ Department of Biotechnology, Sri Venkateswara University, Tirupati, Andhra Pradesh, India. ${ }^{2}$ Department of Botany, Sri Venkateswara \\ University, Tirupati, Andhra Pradesh, India. Email: aishwaryaaa14@gmail.com
}

Received: 19 December 2016, Revised and Accepted: 30 December 2016

ABSTRACT

Aim: The aim of this study was to evaluate the heavy metal resistance potentiality of endophytic fungi isolated from the leaves of Boswellia ovalifoliolata, an endemic medicinal plant of Tirumala Hills.

Methods: Initially, isolation of fungal endophytes was carried out. Isolated fungi were screened for the heavy metal resistance against Co, $\mathrm{Cd}$, $\mathrm{Cu}$ and Zn using growth and evaluated their maximum tolerant capacity. Molecular identification of endophytic fungi was carried out by $18 \mathrm{~S}$ rRNA gene amplification and Sanger's nucleotide sequencing. Phylogenetic tree was constructed using NCBI Clustal W.

Results: Ten different endophytic fungi were isolated from the leaves of $B$. ovalifoliolata. Among the isolated endophytic fungi, five showed resistance to $\mathrm{Co}, \mathrm{Cd}, \mathrm{Cu}$, and $\mathrm{Zn}$. The most resistant fungus was identified as Lasiodiplodia theobromae based on 18S rRNA gene sequencing.

Conclusions: L. theobromae was isolated from B. ovalifoliolata and identified as one of the useful fungi involved in mycoremediation against heavy metal toxicity.

Keywords: Heavy metals, Endophytic fungi, Endemic plant, Bioremediation.

(c) 2017 The Authors. Published by Innovare Academic Sciences Pvt Ltd. This is an open access article under the CC BY license (http://creativecommons. org/licenses/by/4. 0/) DOI: http://dx.doi.org/10.22159/ajpcr.2017.v10i3.16697

\section{INTRODUCTION}

Soil pollution due to heavy metals has become one of the most severe worldwide environmental problems. Industrial activities have been leading to a continuous increase of heavy metal discharge into the environment including cadmium, lead, copper, chromium, and nickel [2] and eventually cause water and soil to be contaminated and become toxic. This problem has attracted considerable public attention because the continued increase of metal levels in soil and water poses a health risk to humans and animals through the food chain or contaminated drinking water [3]. Different conventional methods have been used for the removal and treatment of heavy metal pollution sites such as ion exchange, electrochemical treatment, reverse osmosis, precipitation, evaporation, and sorption $[4,5]$. However, these methods involve application of more reagents, high energy, high cost and result in ineffective and incomplete removal of metals, and also generate toxic sludge [2]. Bioremediation offers most economical and promising option to treat heavy metal in contaminated sites [6]. Different microorganisms are able to reduce the stress placed on plants by the presence of heavy metals, increase the availability of metal for plant uptake and promote plant growth [7,8]. Endophytic fungi are intriguing microbes live inside the healthy plant tissues and exhibits excellent metal-binding capacity [9] and provide more advantages over bacterial bioaugmentation [10]. Not only having the ability to protect against heavy metal toxicity, they also increase nutrient acquisition of host plants and enhance their metabolic activity to combat stress $[11,12]$. A wide range of fungi from all major taxonomic groups have been found in heavy metal polluted soil and some of them have evolved resistance to heavy metals [13]. The resistance and efficiency of endophytic fungi for removal of heavy metals vary greatly. Therefore, it is necessary to isolate and screen heavy metal-tolerant fungi. This study is aimed to isolate and screen heavy metal-tolerant fungi and to evaluate their efficiency to remove heavy metals from solid medium under laboratory conditions.

\section{METHODS}

Isolation of endophytic fungi

Endophytic fungi were isolated from the leaves of Boswellia ovalifoliolata, an endemic medicinal plant of Tirumala hills. The leaves of the B. ovalifoliolata were cut into smaller pieces and surface sterilized with $70 \%$ ethanol, $1 \%$ chlorox, and rinsed with sterilized water $[1,14]$. The plates were incubated at $25^{\circ} \mathrm{C}$ and observed for growth. The pure fungal cultures were transferred periodically onto fresh potato dextrose agar (PDA) plates. Pure cultures of endophytic fungi were stored in slant PDA and used for screening against heavy metals.

\section{Screening of fungal isolates against heavy metals}

Heavy metal-tolerant $(50 \mathrm{ppm})$ fungal isolates were further screened for tolerance to $\mathrm{Co}, \mathrm{Cd}, \mathrm{Cu}$ and $\mathrm{Zn}$ at 100, 200, 400 and $600 \mathrm{ppm}$ of heavy metals individually on PDA. All the fungal isolates were inoculated on PDA medium containing 100, 200, 400 and 600 ppm of each of the four heavy metals separately. The fungal isolate on PDA medium without adding any heavy metal is served as control for comparing the growth of fungal isolates on PDA medium containing different concentration of heavy metals. Observations on the growth of the fungi are recorded as normal growth or absent in comparison to control.

\section{Identification of endophytic fungi} Morphological identification

After 3 days of an incubation period on PDA, a sterile wire loop was used to transfer the isolates from the agar onto a microscope slide. Crystal violet was used to stain the endophytic fungi for easier and better visualization. The slides were then viewed under an inverted microscope and identification was based on fungal morphological keys [15-18]. 


\section{Molecular identification}

DNA extraction

Fungal DNA was extracted for DNA amplification using the thermolysis method devised by Zhang et al. [19]. Pure colonies of fungal isolates were added into $100 \mu \mathrm{l}$ of sterilized water in a $1.5 \mathrm{ml}$ micro centrifuge tube and centrifuged at 10,000 rpm for 1 minute to homogenize it. After centrifugation, the supernatant was discarded and $100 \mu \mathrm{l}$ of the lysis buffer (50 Mm potassium phosphate, $1 \mathrm{mM}$ EDTA, and $1 \%$ glycerol) was pipetted into the micro centrifuge tubes. The tubes were placed in a water bath at $85^{\circ} \mathrm{C}$ for 30 minutes and used for DNA amplification.

\section{DNA amplification}

The DNA amplification method for fungal DNA was conducted according to Netala et al. [20]. The fungal DNA was amplified using $0.6 \mu$ l fungal primers internal transcribed spacer (ITS) 1 (5'-TCC GTA GGT GAA CCT GCG G-3') and 4 (5'-TCC TCC GCT TAT TGA TAT GC-3'), $12.8 \mu$ l deionized distilled water, $15 \mu \mathrm{l}$ of $2 \mathrm{X}$ MyTaqRedMix and $1 \mu \mathrm{l}$ of DNA template. The polymerase chain reaction (PCR) conditions were set up as $95^{\circ} \mathrm{C}$, 3 minutes (initial denaturation); $95^{\circ} \mathrm{C}, 3$ seconds (denaturation); $47^{\circ} \mathrm{C}$, 30 seconds (annealing); $75^{\circ} \mathrm{C}, 2$ minutes (elongation); $72^{\circ} \mathrm{C}, 5$ minutes (final elongation) and $4^{\circ} \mathrm{C}$ (cooling). The PCR tubes containing the MASTER MIX and DNA template were amplified using bioer little genius thermocycler. The PCR products were run in $1 \%$ agarose gel electrophoresis using 1XTAE buffer at $90 \mathrm{~V}$ for 45 minutes and visualized under UV transilluminator.

DNA sequencing and phylogenetic tree analysis

The PCR products were sent to Beijing Genomic Institute, China, for nucleotide sequencing. The sequences obtained were analyzed against the NCBI (USA) database [21], and a phylogenetic tree was constructed from genetic distance and bootstrap values calculated using MEGA5 [22].

\section{RESULTS AND DISCUSSION}

\section{Isolation of endophytic fungi}

Endophytic fungal growth from the leaf tissues of B. ovalifoliolata was first observed after $48 \mathrm{hrs}$ of inoculation. A total of 10 endophytic fungi were isolated from the leave tissues. The surface sterilization protocol was a critical prerequisite for isolating plant endophytic fungi. This study showed that the surface sterilization protocol was effective in removing epiphytic microorganism and that the fungal isolates can be considered to be true endophytic fungi. This made it possible to isolate and characterize endophytic fungi associated with healthy leaves.

\section{Screening of fungal isolates against heavy metals}

Ten fungal isolates were screened against $\mathrm{Co}, \mathrm{Cd}, \mathrm{Cu}$ and $\mathrm{Zn}$. From the preliminary screening 10 fungi which showed different resistance pattern against individual heavy metal (Table 1). The fungi were further screened for their tolerance to $\mathrm{Co}, \mathrm{Cd}, \mathrm{Cu}$ and $\mathrm{Zn}$ at 50,100, 200, 400 and $600 \mathrm{ppm}$. All ten isolates showed resistance Co and $\mathrm{Zn}$ up to $600 \mathrm{ppm}$ but only HEF3 isolate showed resistance to all four heavy metals $\mathrm{Co}, \mathrm{Cd}$, $\mathrm{Cu}$ and $\mathrm{Zn}$ at $600 \mathrm{ppm}$. The difference in metal tolerance may be due to the presence of various strategies of resistance mechanism exhibited by the fungi $[23,24]$. Most studies have been undertaken on filamentous fungal strains and mostly members from the genera Aspergillus, Fusarium, Humicola, and Nannizzia have been reported to possess resistance against heavy metals $[13,23,25]$. Recently, several studies have reported a similar trend among endophytic fungi being able to resist several heavy metals such as copper, zinc, and cadmium [26-28]. The preliminary screening of endophytic fungi against heavy metals showed the order of tolerance to heavy metals are $\mathrm{Cd}<\mathrm{Cu}<\mathrm{Zn}<\mathrm{Co}$. It is observed that as the concentration of heavy metal increased the growth of the fungi decreased due to toxicity of heavy metals. Fungal cell walls are typically composed of the polysaccharides chitin and cellulose and these constituents of the cell wall possess functional groups such as amino, carboxyl, hydroxyl and sulfate which have high metal binding capacities and are believed to have a significant potential for metal binding [29].

\section{Identification of endophytic fungi}

The isolate HEF3 resistant to $\mathrm{Co}, \mathrm{Cd}, \mathrm{Cu}$ and $\mathrm{Zn}$ at $600 \mathrm{ppm}$ was identified as Lasiodiplodia theobromae and the morphological features include characteristic black pigmentation and mycelia was smooth branched, septate and subhylaline hyphae (Fig. 1). The fungus was characterized by PCR amplification of $18 \mathrm{~S}$ rRNA gene using both forward and reverses ITS primers. The amplified PCR product was around the size of $500 \mathrm{bps}$. The Sanger's dideoxy nucleotide sequencing of amplified ITS region (ITS 1-5.8S-ITS 2) of 18 seconds rRNA gene resulted in 517 bps nucleotide sequence. The blast analyses, pairwise, and multiple sequence alignment revealed $98-100 \%$ identity with the sequences of $L$. theobromae strains and is designated as L. theobromae and has been deposited in NCBI Gen Bank (Accession Number KT804649.1). Multiple sequence alignment was carried out using Clustal W2 with default parameters. Phylogenetic tree was constructed by the neighbor-joining method with nucleotide pair wise genetic distance corrections (Fig. 2). L. theobromae is a cosmopolitan fungus with a worldwide distribution in the tropic and sub tropic regions, and there is no evidence of host specificity for the isolate [30,31]. L. theobromae can also be considered as a latent pathogen capable of endophytic infection [32].

\section{CONCLUSION}

Endophytic fungal isolates were isolated from $B$. ovalifoliolata an endemic plant of Tirumala hills. The 10 fungal isolates were screened for their tolerance for the four heavy metals ( $\mathrm{Co}, \mathrm{Cd}, \mathrm{Cu}$ and $\mathrm{Zn}$ ) in PDA medium containing heavy metals from 50 to $600 \mathrm{ppm}$. It was observed that there was decrease in number of fungal isolates tolerance to heavy metals with increasing concentration of heavy metal from 50 to $600 \mathrm{ppm}$. Majority of the fungal isolates were able to tolerate heavy metals up to $400 \mathrm{ppm}$. Among all the fungal cultures only one culture $L$. theobromae HEF3 showed resistance to all four heavy metals $\mathrm{Co}, \mathrm{Cd}, \mathrm{Cu}$ and $\mathrm{Zn}$ up to $600 \mathrm{ppm}$. The endophytic fungi L. theobromae remarkably differed in detoxification behavior from other isolated fungi in this study. The fungus showed a remarkable potential to actively grow in the presence of $\mathrm{Co}, \mathrm{Cd}, \mathrm{Cu}, \mathrm{Zn}$ and reduce heavy metal concentration to less toxic levels. Further investigations

Table 1: Growth of the fungi observed at $600 \mathrm{ppm}$ concentration of heavy metals ( $\mathrm{Co}, \mathrm{Cd}, \mathrm{Cu}$, and $\mathrm{Zn})$

\begin{tabular}{lllll}
\hline Isolates & Co & Cd & Cu & Zn \\
\hline HEF1 & + & - & - & + \\
HEF2 & + & - & - & - \\
HEF3 & + & + & + & + \\
HEF5 & + & - & + & + \\
HEF5 & + & - & + & + \\
HEF6 & + & + & - & + \\
HEF7 & + & - & - & - \\
HEF8 & + & - & - & + \\
HEF9 & + & + & - & + \\
HEF10 & + & - & + & + \\
\hline
\end{tabular}

+: Indicate the presence of growth, -: Indicates absence of growth, Co: Cobalt, Cd: Cadmium, Cu: Copper, Zn: Zinc

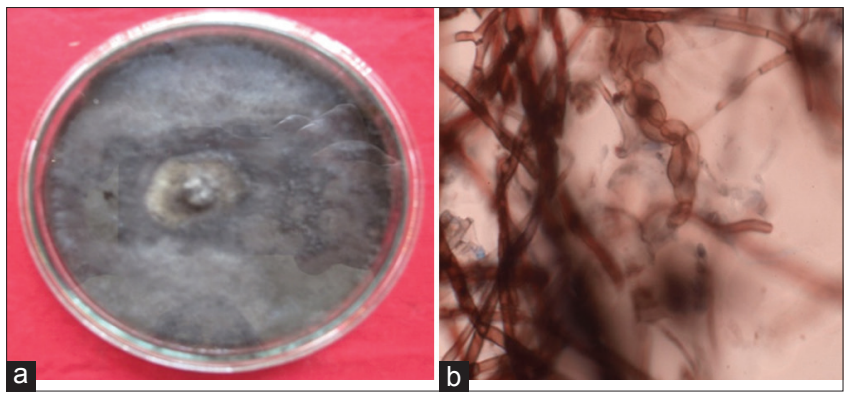

Fig. 1: (a and b) Morphological and microscopical features of Lasiodiplodia theobromae 


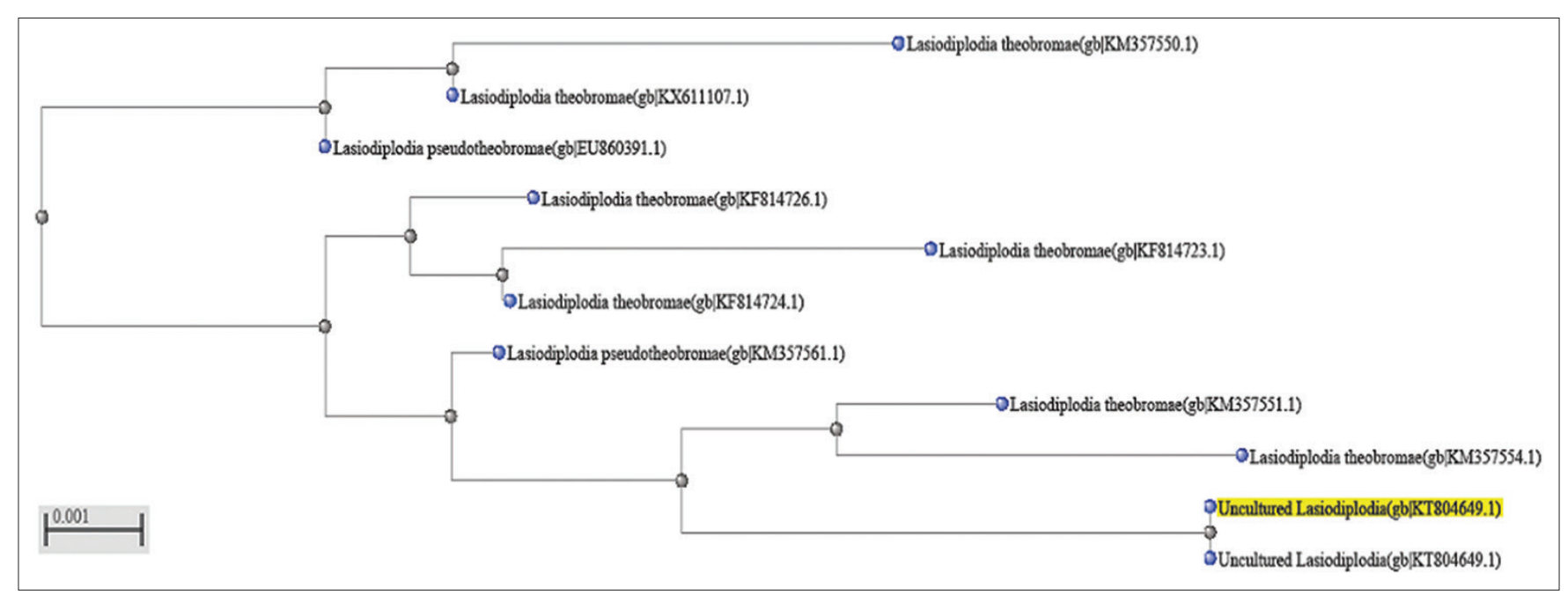

Fig. 2: Phylogenetic analysis of $18 \mathrm{~S}$ rRNA gene of Lasiodiplodia theobromae with other fungal isolates

are needed to know the mechanism involved in fungi for showing resistance.

\section{ACKNOWLEDGMENTS}

We are from Department of Biotechnology, S.V University, Tirupati and our project work was financialy supported by Department of Biotechnology New Delhi Major Research project Sanction Order No.: BT/PR5194/ MED/29/449/2012, Dt:21-09-2012.

\section{REFERENCES}

1. El-Gendy MM, Hassanein NM, Ibrahim EH, El-Baky DH. Evaluation of some fungal endophytes of plant potentiality as low-cost adsorbents for heavy metals uptake from aqueous solution. Aust J Basic Appl Sci 2011;5(7):466-73.

2. Hemambika B, Rani MJ, Kannan VR. Biosorption of heavy metals by immobilized and dead fungal cells: A comparative assessment. J Ecol Nat Environ 2011;3(5):168-75.

3. Granero S, Domingo JL. Levels of metals in soils of Alcalá de Henares, Spain: Human health risks. Environ Int 2002;28(3):159-64

4. Kadirvelu K, Senthilkumar P, Thamaraiselvi K, Subburam V. Activated carbon prepared from biomass as adsorbent: Elimination of $\mathrm{Ni}(\mathrm{II})$ from aqueous solution. Bioresour Technol 2002;81(1):87-90.

5. Luo JM, Xiao X, Luo SL. Biosorption of cadmium (II) from aqueous solutions by industrial fungus Rhizopus cohnii. Trans Nonferrous Met Soc China 2010;20:1104-11

6. Iskandar NL, Zainudin NA, Tan SG. Tolerance and biosorption of copper $(\mathrm{Cu})$ and lead $(\mathrm{Pb})$ by filamentous fungi isolated from a freshwater ecosystem. J Environ Sci (China) 2011;23(5):824-30.

7. Shin MN, Shim J, You Y, Myung H, Bang KS, Cho M, et al. Characterization of lead resistant endophytic Bacillus sp. MN3-4 and its potential for promoting lead accumulation in metal hyperaccumulator Alnus firma. J Hazard Mater 2012;199-200:314-20.

8. He H, Ye Z, Yang D, Yan J, Xiao L, Zhong T, et al. Characterization of endophytic Rahnella sp. JN6 from Polygonum pubescens and its potential in promoting growth and $\mathrm{Cd}, \mathrm{Pb}, \mathrm{Zn}$ uptake by Brassica napus. Chemosphere 2013;90(6):1960-5.

9. Gadd GM. Fungi and yeast metal accumulation. In: Ehrlich HL, Brierley CL, editors. Microbiol Mineral Recovery. New York: McGrawHill; 1990. p. 249-76.

10. D'Annibale A, Rosetto F, Leonardi V, Federici F, Petruccioli M. Role of autochthonous filamentous fungi in bioremediation of a soil historically contaminated with aromatic hydrocarbons. Appl Environ Microbiol 2006;72(1):28-36

11. Selosse MA, Baudoin E, Vandenkoornhuyse P. Symbiotic microorganisms, a key for ecological success and protection of plants. C R Biol 2004;327(7):639-48.

12. Gadd GM. Geomycology: Biogeochemical transformations of rocks, minerals, metals and radionuclides by fungi, bioweathering and bioremediation. Mycol Res 2007;111(1):3-49.

13. Valix M, Tang JY, Malik R. Heavy metal tolerance of fungi. Miner Eng
2001;14(5):499-505.

14. Salini G. Pharmacological profile of mangrove endophytes - A review. Int J Pharm Pharmacol Sci 2005;7(1):6-15.

15. Guba EF. Monograph of the genus Pestalotia de Notaris. Part 1. Phytopathology 1929;19:191-232.

16. Steyaert RL. Contribution to the study of de Pestalotia de Not. and Monochaetia Sacco (Truncatella gen. Nov. and pestalotiopsis gen. Nov.). Bull Jardin Bot État Bruxelles 1949;19:285-354.

17. Jeewon R, Liew EC, Simpson JA, Hodgkiss IJ, Hyde KD. Phylogenetic significance of morphological characters in the taxonomy of Pestalotiopsis species. Mol Phylogenet Evol 2003;27(3):372-83.

18. Maharachchikumbura SS, Guo LD, Chukeatirote E, Bahkali AH, Hyde KD. Pestalotiopsis-morphology, phylogeny, biochemistry and diversity. Fungal Divers 2011;50:167-87.

19. Zhang YJ, Zhang S, Liu XZ, Wen HA, Wang M. A simple method of genomic DNA extraction suitable for analysis of bulk fungal strains. Lett Appl Microbiol 2010;51(1):114-8

20. Netala VR, Kotakadi VS, Bobbu P, Gaddam SA, Tartte V. Endophytic fungal isolate mediated biosynthesis of silver nanoparticles and their free radical scavenging activity and anti microbial studies. 3 Biotech 2016;6(2):132

21. Zhang Z, Schwartz S, Wagner L, Miller W. A greedy algorithm for aligning DNA sequences. J Comput Biol 2000;7(1-2):203-14.

22. Tamura K, Peterson D, Peterson N, Stecher G, Nei M, Kumar S. MEGA5: Molecular evolutionary genetics analysis using maximum likelihood, evolutionary distance, and maximum parsimony methods. Mol Biol Evol 2011;28(10):2731-9.

23. Iram S, Zaman A, Iqbal Z, Shabbir R. Heavy metal tolerance of fungus isolated from soil contaminated with sewage and industrial wastewater. Pol J Environ Stud 2013;22(3):691-7.

24. Venkateswarlu N, Sireesha O, Aishwayra S, Vijaya T, Sreeramulu A. Isolation, screening of rhizosphere fungi antagonistic to rice stem rot disease pathogen Sclerotium oryzae catt. Asian J Pharm Clin Res 2015;8(5):54-7.

25. Ezzouhri L, Castro E, Moya M, Espinola F, Lairini K. Heavy metal tolerance of filamentous fungi isolated from polluted sites in tangier, Morocco. Afr J Microbiol Res 2009;3(2):35-48.

26. Hong JW, Park JY, Gadd GM. Pyrene degradation and copper and zinc uptake by Fusarium solani and Hypocrea lixii isolated from petrol station soil. J Appl Microbiol 2010;108(6):2030-40.

27. Salvadori MR, Lepre LF, Ando RA, Oller do Nascimento CA, Corrêa B. Biosynthesis and uptake of copper nanoparticles by dead biomass of Hypocrea lixii isolated from the metal mine in the Brazilian Amazon Region. PLoS One 2013;8(11):e80519.

28. Deng Z, Zhang R, Shi Y, Hu L, Tan H, Cao L. Characterization of Cd-, $\mathrm{Pb}-, \mathrm{Zn}$-resistant endophytic Lasiodiplodia sp. MXSF31 from metal accumulating Portulaca oleracea and its potential in promoting the growth of rape in metal-contaminated soils. Environ Sci Pollut Res Int 2014;21(3):2346-57.

29. Davis TA, Volesky B, Mucci A. A review of the biochemistry of heavy metal biosorption by brown algae. Water Res 2003;37(18):4311-30.

30. Mohali S, Burgess TI, Wingfield MJ. Diversity and host association of the tropical tree endophyte Lasiodiplodia theobromae revealed using 
simple sequence repeat markers. For Pathol 2005;35:38596.

31. Prabavathy D, Nachiyar V. Antimicrobial and antidiabetic activity of an endophytic fungi isolated from Adathoda beddomei. Int J Pharm Pharm Sci 2013;5(3):780-3.
32. Pandi M, Kumaran RS, Choi YK, Kim HJ, Muthumary J. Isolation and detection of taxol, an anticancer drug produced from Lasiodiplodia theobromae, an endophytic fungus of the medicinal plant Morinda citrifolia. Afr J Biotechnol 2011;10(8):1428-35. 